\title{
Tobacco-free policies at worksites in Kansas
}

\author{
Elizabeth Ablah ${ }^{1 *}$, Frank Dong ${ }^{2}$ and Kurt Konda ${ }^{1}$
}

\begin{abstract}
Background: This study sought to examine the relationship between tobacco-free policies at worksites to worksite demographics such as company size and geographic location.

Methods: Worksites participating in a worksite wellness workshop were asked to complete a worksite wellness instrument, which provided an assessment of their wellness practices already in place in the worksite, including the degree to which tobacco-free policies were in place at the worksite.

Results: At a bivariate level, those more likely to have tobacco-free policies included: urban employers (76.8\% versus 50\% rural employers, $p=0.0001)$; large employers ( $>=250$ employees) $(74.3 \%$ versus $43.1 \%$ small employers ( $<50$ employees), $p=0.0003$ ); and schools (69.4\%) and hospitals (61.5\%) (versus $35.5 \%$, agricultural/ manufacturing employers, $p=0.0125$ ). At the multivariate level, rural employers ( $\mathrm{AOR}=0.47,95 \% \mathrm{Cl} 0.23,0.95)$ and small employers ( $\mathrm{AOR}=0.34,95 \% \mathrm{Cl} 0.16,0.71)$ had decreased odds, compared to their urban and large employer counterparts, of having tobacco-free policies.
\end{abstract}

Conclusions: Rural and smaller employers are less likely to have tobacco-free policies than their urban and large counterparts.

Keywords: Tobacco-free, Policy, Environment, Urban, Rural

\section{Background}

\section{Tobacco usage and costs}

In 2010, 20.2\% of adults in the United States were 'current' smokers [1] and $25.2 \%$ used any tobacco product, such as smokeless tobacco, water pipes, and cigarillos [2]. Tobacco use continues to be the leading cause of preventable death among adults in the United States. The annual average of tobacco-related premature deaths from 2000 to 2004 was 443,000 , approximately $18 \%$ of all deaths at that time [3, 4]. In the United States, $19.0 \%$ of 141 million working adults are current smokers [5].

Beyond the human costs, tobacco use is also costly in terms of healthcare. Healthcare expenditures in the United States topped \$1 trillion dollars in 2006 [6], with employers footing approximately one-third of the bill for healthcare expenditures in the United States [7]. More than half of all US workers (55\%) received healthcare coverage through their employers in 2011, and $68 \%$ of

\footnotetext{
* Correspondence: eablah@kumc.edu

'University of Kansas School of Medicine-Wichita, 1010 North Kansas, Wichita, KS 67214, USA

Full list of author information is available at the end of the article
}

workers either received their healthcare coverage through their employer (or via someone else's employer) [8]. Because such a large proportion of Americans are covered with employer-based healthcare coverage, worksites have a vested interest in controlling healthcare costs associated with tobacco use in their worksites.

The costs associated with tobacco use are substantial, as smokers cost employers an average of 12 times more than non-smokers [9]. The United States' direct medical costs and lost productivity attributable to adults smoking exceed $\$ 300$ billion are $\$ 170$ billion annually [10]. The annual cost to an employer in the United States is approximately $\$ 6000$ per tobacco user [11-13]. Smokers make an average of six more visits per year to healthcare facilities, and the dependents of smokers make four more visits per year to healthcare facilities than nonsmokers and their covered dependents [14].

\section{Tobacco-free policies}

To curtail workplace smoking and tobacco use among employees, worksites have turned to a range of strategies, from moving designated smoking areas to partial or complete tobacco bans on company property, and even prohibitions on tobacco use at any time, on or off 
company grounds $[10,15,16]$. Employee tobacco use has been identified as one of the 10 most impactful modifiable risk factors when predicting employers' healthcare costs [17]. An estimated annual savings of more than $\$ 1000$ in medical expenses for non-smokers and more than $\$ 2000$ for smokers can be realized through these types of policies [18].

In addition to the range of tobacco-free policies that a workplace can implement, there are local, state, and national level laws that can support tobacco cessation in the workplace. In locales with workplace smoking bans, employees experience a range of improved health outcomes, including reduced myocardial infarctions [19], improved respiratory functions [20] and sudden cardiac death [21]. Broad public smoking bans can have many more far-reaching impacts, including reduced incidences of asthmatic symptoms in children [22], pre-term births [23], and hospitalization for angina, stroke, and asthma $[24,25]$.

A tobacco-free workplace can engender cessation attempts among workers [26-29]. Workplaces with tobacco-free policies have employees who are 1.9 to 2.3 times more likely to quit tobacco than employees at worksites in which tobacco is permitted [27]. Predictive modeling of an array of potential anti-tobacco policies and actions indicates that legislatively-mandated total worksite tobacco bans, such as state-level clean air laws prohibiting smoking in any workplace, are among the most efficacious actions that can be taken to reduce smoking prevalence in individuals [30]. Additional factors that can positively influence a worksite's chances of a successful tobacco ban include proper framing of how bans are communicated [31], the availability of additional outside resources to support the bans [32], and visible upper management support [33].

\section{Demographics of tobacco users}

Rural Americans are more likely than urban Americans to: have ever smoked ( $48 \%$ vs. $41 \%)$, currently smoke $(22 \%$ vs $18 \%$ ), be lifetime smokeless tobacco users (22\% vs $14 \%)$, be current smokeless tobacco users ( $6 \%$ vs $2 \%$ ), or have smoking permitted at least sometimes in their work areas (19\% vs 15\%) [34]. Males and those who work for a small employer are also at greater risk of using tobacco $[35,36]$. In fact, worksites with a majority of men, older employees, higher proportions of racial minorities, and with jobs not requiring advanced degrees are more likely to have tobacco-users on their payrolls [1].

While these demographic differences in tobacco usage are known, it is not known what the characteristics of worksites are that have successfully implemented tobacco-free policies. Accordingly, this study sought to identify the characteristics of worksites that are most likely to implement such a policy.

\section{Methods}

\section{Participants}

Worksites in Kansas that completed a baseline Phase I WorkWell Kansas (WorkWell KS) Assessment from January 1, 2013 through October 31, 2014 were included in this study. "Participants" were defined at the worksite level; one assessment was completed per worksite. A convenience sampling frame was utilized.

\section{Procedures}

The study utilized a cross-sectional survey design. Worksites that took participated in a WorkWell KS workshop during the study period were eligible for this study. WorkWell KS "Champions," including KDHE grantees, Chamber of Commerce staff, and local health department staff, were invited by WorkWell KS to recruit worksites across the state to participate, which provided for the largest possible sampling frame of Kansas worksites. The opportunity to participate in WorkWell KS was an opportunity for all workplaces in Kansas, and there was no cost to participate.

Prior to attending their in-person, one and a half day workshop, participating worksites were provided an electronic survey link to complete a baseline survey (see below). Only fully completed surveys from WorkWell KS participants were included in the analysis. Then, at the workshop, participants received reports that were tailored to each participating worksite.

At each worksite, an individual or a team with knowledge of the worksite's demographics, policies, and practices were asked to complete the assessment. These participants vary in position by worksite, but include worksite executives, human resources directors, and wellness coordinators.

\section{Instrument}

The WorkWell KS survey was developed via literature review of relevant worksite assessments identified by a committee of local health department officials, university physicians, the state department of health and environment, and state civic leaders. This team was originally convened in 2008 as the Kansas Worksite Wellness Advisory Committee.

The instrument is a 120-item instrument organized in three major sections, including: 1) organizational demographics, 2) the worksite wellness foundation, and 3) individual wellness items based on selected health topics and strategic approaches to wellness an individual worksite may have utilized. Ten items (including community size, employer size, occupational classification, community name, ethnic, racial and gender composition of the workforce) were contained in the demographic portion of the instrument. Five health topics, including tobacco, physical activity, healthy foods, well-being, and chronic 
disease were represented in the questionnaire. A total of 22 items from the survey were designated as tobacco items, four of which were policy strategies to address tobacco in the workplace (Additional file 1).

\section{Statistical analysis}

A dichotomous outcome variable was created to measure the presence of a policy supporting a tobacco-free workplace based on responses to "Does your worksite have any written policies in place supporting a tobacco-free workplace?" Demographic variables were presented as frequencies and proportions at univariate level. Bivariate chi-square analyses were conducted to compare the outcome variable by the community sizes of each worksite, number of employees at each worksite, industry classifications, gender composition, ethnic composition, and age distribution at each worksite. A logistic regression analysis was conducted to identify predictors associated with having a tobacco-free policy at the worksite. All variables that were significant at bivariate level were selected as possible predictor candidates for the logistic regression. Interactions between predictors were assessed for significance before a decision was made to include those interactions in the logistic regression model. All statistical analyses were conducted using the SAS software for Windows version 9.3 (Cary, NC). All tests were two-sided, and a $p$-value $<0.05$ was considered statistically significant.

\section{Results}

\section{Worksite and community characteristics}

A total of 276 worksites from 29 communities in Kansas were included in the final analysis. The average worksite represented 224 employees, whereas the median employer size was 74 employees (Table 1). Most employers were from rural or 'non-metropolitan' communities (74.6\%), based on US Census Bureau designations for urban/rural status (Census Bureau, 2015). Thirty-seven percent (37.1\%) of worksites reported having fewer than 50 employees, and $37.5 \%$ reported having between 50 and 249 employees. The most common type of place of work was in a 'general office' (29.5\%), followed by 'hospital or healthcare' $(22.9 \%)$, or 'government' (17.6\%). Most worksites $(65.6 \%)$ had more females than males, and $88.2 \%$ of worksites had a majority of their employees younger than 50 years.

\section{Bivariate results}

More than half (57\%) of all worksites reported they had a policy in place supporting a tobacco-free workplace. First, worksites located in urban counties $(76.8 \%)$ were significantly more likely than worksites in rural counties $(50.0 \%)$ to have a policy in place supporting a tobaccofree workplace $(p<0.001)$ (Table 2). Second, worksites with more than 250 employees $(74.3 \%)$ were significantly more likely to have a tobacco-free policy than worksites
Table 1 Community and Worksite Demographics

\begin{tabular}{|c|c|c|}
\hline & Frequency $(N=276)$ & Percent \\
\hline \multicolumn{3}{|l|}{ Population Density } \\
\hline Rural & 206 & 74.6 \\
\hline Urban & 70 & 25.4 \\
\hline \multicolumn{3}{|l|}{ Employer Size } \\
\hline $0-49$ & 102 & 37.1 \\
\hline $50-249$ & 103 & 37.5 \\
\hline 250 or more & 70 & 25.4 \\
\hline \multicolumn{3}{|l|}{ Missing $=1$} \\
\hline \multicolumn{3}{|l|}{ Employer Type } \\
\hline Agriculture/Manufacturing & 31 & 13.7 \\
\hline General Office & 67 & 29.5 \\
\hline Government & 40 & 17.6 \\
\hline Hospital or Healthcare & 52 & 22.9 \\
\hline Schools or Education & 36 & 15.9 \\
\hline "Other" & 1 & 0.4 \\
\hline \multicolumn{3}{|l|}{ Missing $=49$} \\
\hline \multicolumn{3}{|l|}{ Gender } \\
\hline$>=50 \%$ were females & 168 & 65.6 \\
\hline$>=50 \%$ were males & 88 & 34.4 \\
\hline Missing & 20 & \\
\hline \multicolumn{3}{|l|}{ Age } \\
\hline $\begin{array}{l}1-50 \% \text { of workers who were } 50 \text { years } \\
\text { and older }\end{array}$ & 202 & 88.2 \\
\hline $\begin{array}{l}51 \% \text { or more of workers who were } \\
50 \text { years and older }\end{array}$ & 27 & 11.8 \\
\hline Missing & 47 & \\
\hline \multicolumn{3}{|l|}{ Ethnicity } \\
\hline $\begin{array}{l}\text { Lower than the Kansas Hispanic } \\
\text { percentage }(11.2 \%)\end{array}$ & 196 & 81.3 \\
\hline $\begin{array}{l}\text { Higher than the Kansas Hispanic } \\
\text { percentage }(11.2 \%)\end{array}$ & 45 & 18.7 \\
\hline Missing & 35 & \\
\hline \multicolumn{3}{|l|}{ Composition of the Workforce } \\
\hline $1-25 \%$ manual labor & 143 & 56.75 \\
\hline $26-50 \%$ manual labor & 30 & 11.9 \\
\hline $51-75 \%$ manual labor & 43 & 17.06 \\
\hline 76-100\% manual labor & 36 & 14.29 \\
\hline Missing & 24 & \\
\hline \multicolumn{3}{|l|}{ Tobacco-free Policy } \\
\hline Has tobacco-free policy & 156 & 56.7 \\
\hline Does not have tobacco-free policy & 119 & 43.3 \\
\hline Missing & ‘ & \\
\hline
\end{tabular}

with 50 to 249 employees (58.3\%) and worksites with fewer than 50 employees $(43.1 \%, p<0.001)$. Third, worksites in the agriculture/manufacturing sectors 
Table 2 Worksite Tobacco-Free Policies

\begin{tabular}{|c|c|c|c|}
\hline & No Tobacco-Free Policy $(n=119)$ & Tobacco-Free $\operatorname{policy}(n=156)$ & $P$-value \\
\hline Population Density & & & 0.0001 \\
\hline Rural & $103(50 \%)$ & $103(50 \%)$ & \\
\hline Urban & $16(23.2 \%)$ & $53(76.8 \%)$ & \\
\hline Employer size & & & 0.0003 \\
\hline $0-49$ & $58(56.9 \%)$ & $44(43.1 \%)$ & \\
\hline $50-249$ & $43(41.8 \%)$ & $60(58.3 \%)$ & \\
\hline 250 or more & $18(25.7 \%)$ & $52(74.3 \%)$ & \\
\hline Employer Type* & & & 0.0125 \\
\hline Agriculture/Manufacturing & $20(64.5 \%)$ & $11(35.5 \%)$ & \\
\hline General Office & $40(59.7 \%)$ & $27(40.3 \%)$ & \\
\hline Government & $18(45 \%)$ & $22(55 \%)$ & \\
\hline Hospital or Healthcare & $20(38.5 \%)$ & $32(61.5 \%)$ & \\
\hline Schools or Education & $11(30.6 \%)$ & $25(69.4 \%)$ & \\
\hline "Other" & $1(100 \%)$ & $0(0 \%)$ & \\
\hline \multicolumn{4}{|l|}{ Missing $=48$} \\
\hline Gender & & & 0.0474 \\
\hline$>=50 \%$ were females & $62(37.1 \%)$ & $105(62.9 \%)$ & \\
\hline$>=50 \%$ were males & $44(50 \%)$ & $44(50 \%)$ & \\
\hline \multicolumn{4}{|l|}{ Missing $=20$} \\
\hline Age & & & 0.7233 \\
\hline $1-50 \%$ of workers who were 50 years and older & $82(40.6 \%)$ & $120(59.4 \%)$ & \\
\hline $51 \%$ or more of workers who were 50 years and older & $10(37 \%)$ & $17(63 \%)$ & \\
\hline \multicolumn{4}{|l|}{ Missing $=47$} \\
\hline Ethnicity & & & 0.1858 \\
\hline Lower than the Kansas Hispanic percentage (11.2\%) & $79(40.3 \%)$ & $117(59.7 \%)$ & \\
\hline Higher than the Kansas Hispanic percentage (11.2\%) & $23(51.1 \%)$ & $22(48.9 \%)$ & \\
\hline \multicolumn{4}{|l|}{ Frequency Missing = 35} \\
\hline Composition of the workforce & & & 0.1099 \\
\hline $1-25 \%$ manual labor & $56(39.2 \%)$ & $87(60.8 \%)$ & \\
\hline 26-50\% manual labor & $14(46.7 \%)$ & $16(53.3 \%)$ & \\
\hline \multicolumn{4}{|l|}{$51-75 \%$ manual labor } \\
\hline 76-100\% manual labor & $22(61.1 \%)$ & $14(38.9 \%)$ & \\
\hline Frequency Missing = 24 & & & \\
\hline
\end{tabular}

${ }^{*} p$-value calculation was based on the exclusion of other category in the employer type

(35.5\%) were less likely to have a tobacco-free policy than white-collar settings, like those in the hospital/ healthcare industrial sector $(61.5 \%)$ or worksites in the education or school sectors $(69.4 \%, p=0.013)$. Finally, worksites with predominantly male employees (50\%) were significantly less likely to have a tobacco-free policy in place than employers with a majority of female employees $(62.9 \%, p=0.047)$. Age, ethnicity, and manual labor percentage were not associated with tobacco-free policy in worksite (all three $p$-values $>0.05$, Table 2 ).

\section{Logistic regression results}

A multivariable logistic regression was conducted to identify factors associated with worksites having a tobacco-free policy. Possible factors included: population density, employer size, employer type, and gender composition. Worksites in rural areas were significantly less likely to have tobacco-free policies in place than worksites in urban areas $(\mathrm{OR}=0.47,95 \%$ confidence interval (CI): 0.23-0.95) (Table 3). Likewise, small employers (with between 1 and 49 employees) 
Table 3 Odds Ratio Estimates with 95\% Confidence Interval for Having a Tobacco-Free Policy

\begin{tabular}{|c|c|c|}
\hline & Unadjusted Odds Ratio & Adjusted Odds Ratio \\
\hline \multicolumn{3}{|l|}{ Population Density } \\
\hline Rural & $0.31(0.16,0.57)$ & $0.47(0.23,0.95)$ \\
\hline Urban & Reference & Reference \\
\hline \multicolumn{3}{|l|}{ Employer Size } \\
\hline $1-49$ & $0.27(0.14,0.52)$ & $0.34(0.16,0.71)$ \\
\hline $50-249$ & $0.48(0.25,0.94)$ & $0.54(0.26,1.12)$ \\
\hline 250 or more & Reference & Reference \\
\hline \multicolumn{3}{|l|}{ Employer Type } \\
\hline Agriculture/Manufacturing & $0.24(0.09,0.67)$ & Not significant in multivariable logistic regression \\
\hline General Office & $0.3(0.13,0.7)$ & \\
\hline Government & $0.54(0.21,1.38)$ & \\
\hline Hospital or Healthcare & $0.7(0.29,1.74)$ & \\
\hline Schools or Education & Reference & \\
\hline \multicolumn{3}{|l|}{ Gender } \\
\hline$>=50 \%$ were females & Reference & Not significant in multivariable logistic regression \\
\hline$>=50 \%$ were males & $0.59(0.35,1)$ & \\
\hline \multicolumn{3}{|l|}{ Composition of the workforce } \\
\hline $1-25 \%$ manual labor & $2.44(1.15,5.17)$ & Not significant in multivariable logistic regression \\
\hline $26-50 \%$ manual labor & $1.8(0.67,4.79)$ & \\
\hline $51-75 \%$ manual labor & $1.65(0.67,4.04)$ & \\
\hline 76-100\% manual labor & Reference & \\
\hline \multicolumn{3}{|l|}{ Age } \\
\hline $1-50 \%$ of workers who were 50 years and older & $0.86(0.38,1.97)$ & Not significant in multivariable logistic regression \\
\hline $51 \%$ or more of workers who were 50 years and older & Reference & \\
\hline \multicolumn{3}{|l|}{ Ethnicity } \\
\hline Lower than the Kansas Hispanic percentage (11.2\%) & Reference & Not significant in multivariable logistic regression \\
\hline Higher than the Kansas Hispanic percentage (11.2\%) & $0.65(0.34,1.24)$ & \\
\hline
\end{tabular}

were significantly less likely than large worksites (with more than 250 employees) to have tobacco-free policies in place $(\mathrm{OR}=0.34,95 \% \mathrm{CI} 0.16,0.71)$. Medium-sized employers (between 50 and 249 employees) were less likely to have a tobacco-free policy in place than large-sized employers $(\mathrm{OR}=0.54,95 \%$ CI $0.26,1.12$ ), though the difference failed to reach statistical significance (Table 2).

\section{Discussion}

More worksites had tobacco-free policies in place (56.7\%) than those that did not (43.3\%). This percentage (56.7\%) lags behind the percentages in other state-based studies, as it is less than that of the $90 \%$ of worksites in Texas with tobacco policies [37], and the 68\% of Minnesota worksites with written tobacco policies [38], but there were important differences in how likely a given worksites was to have such a policy at a bivariate and univariate level.
Worksites in urban counties and worksites with more employees were more likely to have tobacco-free policies in place than worksites in rural areas and worksites with fewer employees. These differences are especially important given that smoking is more prevalent in rural areas [39] and that the majority of employees in Kansas' urban areas worked for large employers with greater than 500 employees $[40,41]$. In fact, $27 \%$ of adults in rural areas report being current smokers, whereas $18 \%$ of adults in large metropolitan statistical areas (MSAs) are current smokers [1].

Large worksites in Kansas were nearly three times as likely as small employers to support tobacco-free policies. This is similar to a pattern observed in a similar statewide study of Minnesota employers, which suggested a 36\% increased likelihood for large employers to have written tobacco policies in place more than smaller employers $(89 \%$ v 65\%) [38]. In a largely rural and geographically large 
state such as Kansas, it is especially important for rural and smaller employers to more fully embrace tobacco-free policies in the workplace, as the majority of worksites in the sample were located in rural, non-metropolitan statistical area communities (76\%) and had fewer than $250 \mathrm{em}$ ployees $(76 \%)$.

In addition to the differences at the community and worksite level that are perhaps best addressed through policy, it is also important to consider individual-level demographic characteristics in tobacco use that can also be addressed through evidence-based cessation programs (e.g., counseling and medication). A tobacco-free policy, implemented in conjunction with evidence-based smoking cessation programs, can double the likelihood that an employee will stop smoking [42].

The current study adds to individual-level data and risk factors in use of tobacco by examining the worksite and its policies. This focus on population health is a necessary shift, as worksite policies, when implemented with other evidence-based strategies, can influence the employer's financial health and productivity in addition to improving the physical health of employees, on and off the job.

\section{Limitations}

These are self-reported data; employers completed these surveys in advance of a worksite wellness workshop for which they had been recruited to participate. While WorkWell KS was publically promoted, and participation was actively solicited via WorkWell KS Champions statewide, this sample does not necessarily represent Kansas worksites. Even though the workshop was free, participation required a time commitment from participants, which could have resulted in selection bias. It could be assumed that the entire sample was at least somewhat interested in worksite wellness, although the WorkWell KS Champions were charged with recruiting worksites that were influential in their communities, not necessarily those with an interest in health. Additionally, the social pressure to give the 'right' answers may have inflated some results. However, there is no reason to assume any response biases were not evenly distributed across worksites by community size or worksite size; any patterns of differences observed were likely unaffected by any possible response biases. Finally, this study was conducted in a cross-sectional design, so causation is impossible to determine.

\section{Conclusions}

Tobacco policies were common across participating worksites, but important differences exist. Rural and small employers, which are the predominant types of employers in Kansas, were less likely to have tobaccofree policies in place compared to their urban and large counterparts. Future policies and programs that attempt to address tobacco usage in rural areas and among small employers may need to make more comprehensive efforts to reducing tobacco use.

\section{Additional file}

Additional file 1:(PDF $619 \mathrm{~kb})$

Acknowledgements

Not applicable.

\section{Funding}

This study was conducted based on research and data collected as part of grants funded by the Kansas Health Foundation, the Kansas Department of Health and Environment, and from the Centers for Disease Control and

Prevention (CDC). Funding agencies supported the mission of WorkWell KS, which included the data analyzed in the current study, but funders played no active role in the drafting or analysis of this manuscript.

Availability of data and materials

The datasets used and/or analyzed during the current study are available from the corresponding author on reasonable request.

Authors' contributions

KK interpreted the data. FD assisted with the data analysis and constructed the tables. EA oversaw all research activities and edited the manuscript. All authors read and approved the final manuscript.

Competing interests

The authors declare that they have competing interests.

Consent for publication

Not applicable.

Ethics approval and consent to participate

This study was presented to the University of Kansas School of MedicineWichita's Human Subjects Committee and was deemed not human subjects research. As such, no formal consent was required. However, the introduction page to the survey included standard consent-verbiage including information about the survey purpose, voluntary nature of completion, data aggregation, and contact information for questions about the survey. Participants were then able to advance past the introduction page to complete the survey or opt-out of completing the survey by simply exiting the survey.

\section{Publisher's Note}

Springer Nature remains neutral with regard to jurisdictional claims in published maps and institutional affiliations.

\section{Author details}

${ }^{1}$ University of Kansas School of Medicine-Wichita, 1010 North Kansas, Wichita, KS 67214, USA. ${ }^{2}$ Western University of Health Sciences, 309 E 2nd Street, Pomona, CA 91766, USA.

Received: 21 July 2016 Accepted: 20 April 2017

Published online: 12 June 2017

References

1. Schoenborn CA, Adams PF, Peregoy JA. Health behaviors of adults: United States, 2008-2010. National Center for Health Statistics. Vital Health Stat 10. 2013;(257):1-184.

2. King BA, Dube SR, Tynan MA. Current tobacco use among adults in the United States: findings from the National Adult Tobacco Survey. Am J Public Health. 2012;102(11):e93-e100.

3. Centers for Disease Control and Prevention. Smoking-attributable mortality, years of potential life lost, and productivity losses - United States, 2000 2004. MMWR. 2008;57(45):1226-8. 
4. Centers for Disease Control and Prevention. Deaths: final data for 2004. Natl Vit Stat Rep. 2007;55(19):1226-8.

5. Syamlal G, Mazurek JM, Hendricks SA, Jamal A. Cigarette smoking trends among US working adult by industry and occupation: findings from the 2004-2012 National Health Interview Survey. Nicotine Tob Res. 2015;17(5): 599-606.

6. Poisal JA, Truffer C, Smith S, et al. Health spending projections through 2016: Modest changes obscure part D's impact. Health Affair. 2007;26(2): w242-53.

7. Koretz G. Employers tame medical costs: but workers pick up a bigger share. Bus Week. 2000;3664:26.

8. DeNavas-Walt C, Proctor BD, Smith JC. "income, poverty, and health insurance coverage in the United States: 2011," current population reports, P60-243, U.S. Census Bureau, Washington DC, 2012.

9. Musich S, Napier D, Edington D. The association of health risks with workers' compensation costs. JOEM. 2001;43(6):534-41.

10. Osinubi OY, Slade J. Tobacco in the workplace. J Occup Med. 2002; 17(1), 137-58.

11. Centers for Disease Control and Prevention. Annual smoking-attributable mortality, years of potential life lost, and productivity losses — United States, 1997-2001. MMWR. 2005;54(25):625-8.

12. Halpern M, Shikiar R, Rentz A, Khan Z. Impact of smoking status on workplace absenteeism and productivity. Tob Control. 2001;10(3):233-8.

13. Bertera RL. The effects of behavioral risks on absenteeism and health-care costs in the workplace. J Occup Med. 1991;33(11):1119-24.

14. Berman M, Crane R, Seiber E, Munur M. Estimating the cost of a smoking employee. Tob Control. 2014;23(5):428-33.

15. Voigt K. Ethical concerns in tobacco control nonsmoker and "Nonnicotine" hiring policies: the implications of employment restrictions for tobacco control. Am J Public Health. 2012;102(11):2013-8.

16. Stuber J, Galea S, Link BG. Smoking and the emergence of a stigmatized social status. Soc Sci Med. 2008;67(3):420-30.

17. Goetzel RZ, Pei X, Tabrizi MJ, et al. Ten modifiable health risk factors are linked to more than one-fifth of employer-employee health care spending. Health Affair. 2012;31(11):2474-84.

18. Kooreman H, Judson-Patrick AM, Wright E. The Economic Impact of SmokeFree Policies on Business and Health. March 2009. http://www.in.gov/isdh/ tpc/files/UUCtrforHealthPolicySmokeFreeReport.pdf . Accessed 2 May 2017.

19. Sargent RP, Shepard RM, Glantz SA. Reduced incidence of admissions for myocardial infarction associated with public smoking ban: before and after study. BMJ. 2004;328(7446):977-80.

20. Farrelly MC, Nonnemaker JM, Chou R, Hyland A, Peterson KK, Bauer UE. Changes in hospitality workers' exposure to secondhand smoke following the implementation of New York's smoke-free law. Tob Control. 2005:4(4):236-41.

21. Hurt RD, Weston SA, Ebbert JO, McNallan SM, Croghan IT, Schroeder DR, Roger VL. Myocardial infarction and sudden cardiac death in Olmsted County, Minnesota, before and after smoke-free workplace laws. Arch Intern Med. 2012;172(21):1635-41.

22. Dove MS, Dockery DW, Connolly GN. Smoke-free air laws and asthma prevalence, symptoms, and severity among nonsmoking youth. Pediatrics. 2011;127(1):102-9.

23. Page RL, Slejko JF, Libby AM. A citywide smoking ban reduced maternal smoking and risk for preterm births: A Colorado natural experiment. J Women's Health. 2012;21(6):621-7.

24. Herman PM, Walsh ME. Hospital admissions for acute myocardial infarction, angina, stroke, and asthma after implementation of Arizona's comprehensive statewide smoking ban. Am J Public Health. 2011;101(3): 491-6.

25. Sargent JD, Demidenko E, Malenka DJ, Li Z, Gohlke H, Hanewinkel R. Smoking restrictions and hospitalization for acute coronary events in Germany. Clin Res Cardiol. 2012;101(3):227-35.

26. Knowlden AP, Ickes MJ, Sharma M. Systematic analysis of tobacco treatment interventions implemented in worksite settings. J Subst Abus. 2014;19(4): 283-94

27. Ham DC, Przybeck T, Strickland JR, Luke DA, Bierut LJ, Evanoff BA. Occupation and workplace policies predict smoking behaviors: analysis of national data from the current population survey. JOEM. 2011;53(11):1337.

28. Volpp KG, Troxel AB, Pauly MV, et al. A randomized, controlled trial of financial incentives for smoking cessation. New Engl J Med. 2009;360(7): 699-709.
29. Berman M, Crane R. Mandating A. Tobacco-free workforce: a convergence of Business and public health interests. William Mitchell Law Rev 2008; 34(4): 1651-1674.

30. Nagelhout GE, Levy DT, Blackman K, Currie L, Clancy L, Willemsen MC. The effect of tobacco control policies on smoking prevalence and smokingattributable deaths. Findings from the Netherlands SimSmoke tobacco control policy simulation model. Addiction. 2012;107(2):407-16.

31. Fahy D, Trench B, Clancy L. Communicating contentious health policy lessons from Ireland's workplace smoking ban. Health Promot Pract. 2012; 13(3):331-8.

32. Laing SS. Increasing evidence-based workplace health promotion best practices in small and low-wage companies, Mason County, Washington, 2009. Prev Chronic Dis. 2012;9:E83.

33. Lawn S, Campion J. Factors associated with success of smoke-free initiatives in Australian psychiatric inpatient units. Psychiatr Serv. 2010;61(3):300-5.

34. Vander Weg MW, Cunningham CL, Howren MB, Cai X. Tobacco use and exposure in rural areas: findings from the behavioral risk factor surveillance system. Addict Behav. 2011;36(3):231-6.

35. Hannon PA, Garson G, Harris JR, Hammerback K, Sopher CJ, Clegg-Thorp C. Workplace health promotion implementation, readiness, and capacity among midsize employers in low-wage industries: a National Survey. JOEM. 2012; Oct 19.

36. Syamlal G, Mazurek JM, Dube SR. Gender differences in smoking among US working adults. Am J Public Health. 2014;47(4):467-75.

37. Texas Business Group on Health. Texas Employers Benchmarking Survey: Tobacco Use Policies and Programs - 2014. September 26, 2014. http:// healthcare.dmagazine.com/2014/09/26/survey-texas-employers-largelystomping-out-smoking/; Accessed 2 Oct 2014.

38. Minnesota Department of Health. 2012 Minnesota Worksite Survey. 2012. http://www.health.state.mn.us/divs/oshii/worksite/docs/ worksitesurveysummary.pdf ; Accessed 2 May 2017.

39. Eberhardt MS, Pamuk ER. The importance of place of residence: examining health in rural and nonrural areas. Am J Public Health. 2004:94(10):1682-6.

40. United States Census Bureau 2015. Statistics of US Business Annual Data. 2012. https://www.census.gov/data/tables/2012/econ/susb/2012-susbannual.html. Accessed 2 May 2017.

41. Small Business Administration. State, Metropolitan Statistical Area (MSA) \& County static data. 2015. https://www.sba.gov/advocacy/firm-size-data Accessed 2 May 2017.

42. Hanna N, Mulshine J, Wollins DS, Tyne C, Dresler C. Tobacco cessation and control a decade later: American Society of Clinical Oncology policy statement update. J Clin Oncol. 2013;31(25):3147-57.

\section{Submit your next manuscript to BioMed Central and we will help you at every step:}

- We accept pre-submission inquiries

- Our selector tool helps you to find the most relevant journal

- We provide round the clock customer support

- Convenient online submission

- Thorough peer review

- Inclusion in PubMed and all major indexing services

- Maximum visibility for your research

Submit your manuscript at www.biomedcentral.com/submit 